\title{
Cytology of Fibrous Roots from Citrus Blight-Affected Trees
}

\author{
A. G. C. Lindbeck, Assistant Professor, Department of Biology, University of Central Florida, Orlando 32816; and \\ R. H. Brlansky, Professor, University of Florida, IFAS, Citrus Research and Education Center, 700 Experiment \\ Station Road, Lake Alfred 33850
}

\begin{abstract}
Lindbeck, A. G. C., and Brlansky, R. H. 2000. Cytology of fibrous roots from citrus blightaffected trees. Plant Dis. 84:164-167.

Citrus blight is an economically important decline disease of citrus in various areas of the world. The cause of citrus blight is unknown, but transmission via root grafting has been demonstrated. Root tissue from fibrous roots of citrus blight-affected and healthy citrus trees were compared. Amorphous plugs of the type previously observed in the trunk xylem and large roots of blighted trees were also found in the fibrous roots. The plugs were yellow to light gold in color, gave a positive staining reaction for the presence of lignin, and were retained when kept overnight in water. With scanning electron microscopy the amorphous plugs appeared to be solid, occluding part or all of the vessel. These plugs have previously been implicated in the reduction of water transmission in blighted trees.
\end{abstract}

Additional keywords: root morphology, water conductivity, young tree decline

Citrus blight is a decline disease affecting mature, fruit-bearing citrus trees in Florida. Diseases similar or identical to blight also occur in the citrus-producing regions of Brazil, Argentina, Australia, South Africa, Cuba, and Uruguay (2). While the etiology of citrus blight is unknown, a number of symptoms are considered to be characteristic of the disease. These include permanent wilt and canopy decline (14), delayed blooming (14), leaf zinc deficiency symptoms prior to decline or in new flushes after decline sets in (15), elevated zinc levels in the trunk xylem $(15,19)$, reduced water conduction in the xylem of the trunk and roots $(6,9,12,20,21)$, and the presence of pathogenesis-related proteins $(1,7)$. In the field, canopy decline together with reduced or no water uptake in the syringe injection water test is considered to be diagnostic for citrus blight (10).

Canopy decline associated with citrus blight is a result of the reduced water flow in the xylem (4). Studies of water transmission in intact trees $(20,21)$ suggested that the major restriction of water flow occurs in the trunk and major scaffold limbs and that the restriction of water flow in the roots is a function of the reduction of water flow in the trunk (21). Two types of plugs have been identified in the lumens of

Corresponding author: R. H. Brlansky

E-mail: rhby@lal.ufl.edu

Florida Agricultural Experiment Station Journal Series R-07088.

Accepted for publication 5 November 1999.

Publication no. D-1999-1215-01R

(c) 2000 The American Phytopathological Society xylem vessels of blighted citrus trees (6): a fibrous mass referred to as a filamentous plug and a solid-appearing amorphous plug. Initial histological studies suggested that the presence of filamentous plugs in the xylem in the roots of blight-affected trees was responsible for the reduced water flow (5). However, it was found that the filamentous plugs, while more prevalent in diseased trees (13), were also found in healthy trees and trees with a number of other diseases $(3,11)$. Studies of tissue adjacent to the vascular cambium from the trunks of blighted trees suggested that the primary cause of reduced water flow is amorphous plugs in the xylem $(11,16)$. Brlansky et al. (4) found a correlation between the number of amorphous plugs in the xylem and the reduction of water flow in the xylem. No such correlation could be demonstrated for the filamentous plugs.

While amorphous plugs in the xylem of the trunk, major limbs, and large roots may be responsible for the reduction in water flow in blighted citrus trees, it is not clear whether similar plugging also occurs in the fibrous roots. In several studies, it was reported that water flow was reduced in excised roots from blighted trees, suggesting that plugging does occur $(9,12)$. The purpose of this study was to examine fibrous roots from blight-affected citrus trees growing in Florida and determine the ultrastructural and cytological changes occurring in the fibrous roots of these trees by comparison with healthy trees from California, where blight has not been reported, and Florida.

\section{MATERIALS AND METHODS}

Plant tissue. All tissue samples were obtained from field-grown sweet orange scions on Carrizo citrange root stock (Citrus sinensis (L.) Osbeck $\times$ Poncirus trifoliata (L.) Raf.). Tissue samples were fixed in the field or placed on ice and fixed in the laboratory as described below. Blighted trees were selected on the basis of their appearance, lack of water uptake in the syringe water injection test, and the presence of blight-associated proteins. Fibrous root samples were taken from lateral roots attached to large roots (originating from the base of the trunk) that had shown a lack of water uptake in the syringe water injection test. Fibrous roots ( 2 to $3 \mathrm{~mm}$ diameter) attached directly to the lateral roots ( 1 to $2 \mathrm{~cm}$ diameter) were designated primary fibrous roots, and fibrous roots ( 1 to $2 \mathrm{~mm}$ diameter) attached to the primary fibrous roots were designated secondary fibrous roots for purposes of identification. Trunk cores also were taken from these trees to confirm the presence of amorphous plugging in the trunk xylem. Roots were collected from seven blighted trees in two commercial groves in the central Florida area and compared with roots from sweet orange scions on Carrizo citrange rootstock grown in California (one tree) and Florida (two trees).

Tissue preparation. Primary and secondary fibrous roots (five samples of each type per tree) were fixed for $2 \mathrm{~h}$ in $3 \%$ glutaraldehyde in $0.066 \mathrm{M}$ phosphate buffer ( $\mathrm{pH}$ 6.8), postfixed with $1 \% \mathrm{OsO}_{4}$ in phosphate buffer, dehydrated in a stepwise acetone series $(25,50,75,90$, and $100 \%)$ for $15 \mathrm{~min}$ each followed by $1 \mathrm{~h}$ in $100 \%$ acetone, then left overnight in $100 \%$ acetone. The tissue was then embedded in Spurr's resin. Half-micron sections for light microscopy were cut on a Reichert Ultracut E ultramicrotome (C. Reichert Optische Werke AG, Vienna, Austria). The sections were stained with methylene blue/azure A for $1 \mathrm{~min}$, counterstained with basic Fucshin for $30 \mathrm{~s}$, and viewed using an Olympus model $\mathrm{AH}-2$ light microscope (Olympus Optical Co. Ltd., Tokyo, Japan).

Primary and secondary fibrous roots (five samples of each type per tree) were prepared for scanning electron microscopy by fixing in 3\% glutaraldehyde in $0.066 \mathrm{M}$ phosphate buffer ( $\mathrm{pH} 6.8$ ) for $2 \mathrm{~h}$ at room temperature. The tissue was washed three times for 15 min each in phosphate buffer, postfixed in $1 \% \mathrm{OsO}_{4}$ in phosphate buffer for $2 \mathrm{~h}$ at room temperature, and washed a further three times for $15 \mathrm{~min}$ each in phosphate buffer. The tissue was dehydrated in an ethanol series $(25,50,75,90$, 
and $100 \%$ ) for 15 min each, followed by $100 \%$ ethanol for $1 \mathrm{~h}$, then left overnight in $100 \%$ ethanol. The tissue was critical point dried in a Ladd critical point drier (Ladd Research Industries, Burlington, Vermont), mounted on scanning electron microscope (SEM) stubs, and sputter coated with $10^{-3}$ $\mathrm{nm}$ gold-palladium in a Ladd sputter coater. Specimens were viewed with a Hitachi model S-530 scanning electron microscope (Hitachi, Ltd., Tokyo, Japan).

Primary and secondary fibrous roots (five samples of each type per tree) for

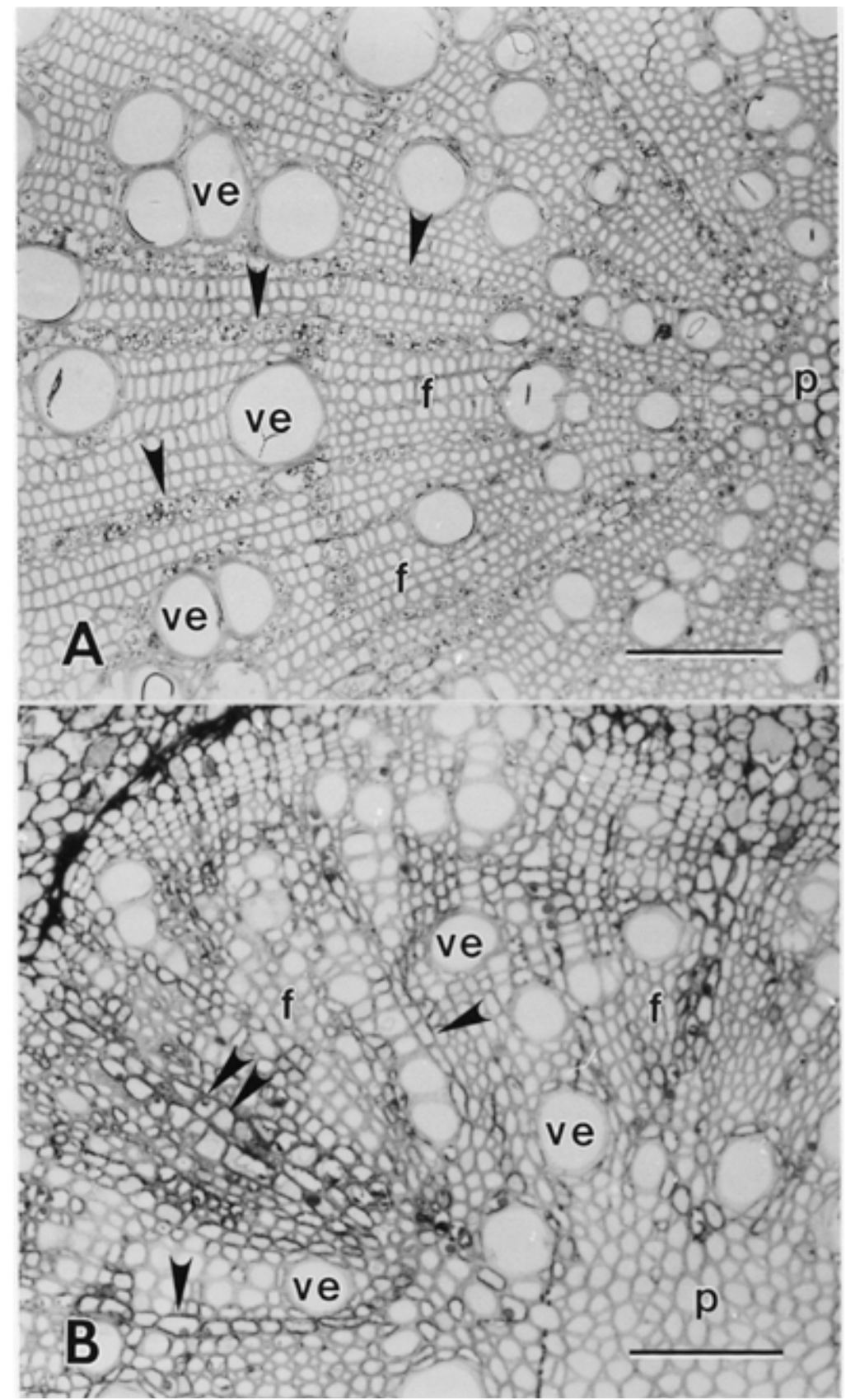

Fig. 1. Transverse sections of fibrous roots from healthy (A) and blighted (B) citrus trees. In healthy tissue (A) the xylem layer is divided into sectors by rays (arrowheads), which usually consist of a uniseriate file of cells extending from the pith (p) to the vascular cambium. The fiber cells (f) in each sector are arranged in concentric layers around the pith and extend out to the vascular cambium. Vessel elements (ve) are randomly interspersed among the fiber cells in each sector. In blighted tissue (B) the regular structure of the xylem layer is significantly distorted. Fiber cells do not form concentric layers around the pith. Rays (arrowheads) are less likely to be parallel to the radius of the root and can be biseriate (double arrowhead). (All bars $=100 \mu \mathrm{m})$
Transverse sections, $25 \mu \mathrm{m}$ thick, of the trunk cores 2 to $3 \mathrm{~cm}$ from the bark and from lateral roots were cut using a Spencer sliding microtome after embedding the tissue in Tissue-Tek O.C.T. compound and cooling with carbon dioxide. Some sections were stained with phloroglucinol, as described above. Sections were viewed with an Olympus model AH-2 light microscope. Samples from the same part of the core and lateral roots were also prepared for SEM as described above.

\section{RESULTS}

Fibrous root morphology. The morphology of fibrous roots of blight-affected citrus trees was investigated in plasticembedded sections of material excised from the 1- to 2-mm-diameter fibrous roots, approximately 0.5 to $1.0 \mathrm{~cm}$ from the tips. This part of the root represents the zone in which the nascent cells emerging from the meristem complete differentiation into functioning vascular tissue (8), and it is also a major zone of the root involved in water uptake (18).

Compared with healthy tissue, xylem in blight-affected tissue appeared to be less organized (Fig. 1). The xylem layer in healthy tissue (Fig. 1A) is divided radially into sectors by rays consisting of a uniseriate line of cells extending from the pith to the vascular cambium. In healthy tissue, these cells, and the fiber cells that form the bulk of the tissue bounded by the rays, are arranged in a highly organized fashion into concentric layers of cells around the pith and extending out to the vascular cambium. The vessel elements of the xylem vascular system are randomly interspersed among the fibers. In blight-affected tissue (Fig. 1B), the regular arrangement of cells was not as apparent. The fiber cells were irregular or circular in shape and did not form regular circular layers. The ray cells appeared to be larger and more elongated along the radial axis than ray cells in healthy tissue. Rays were less likely to be aligned parallel to the radius of the root (Fig. 1B) and more likely to be biseriate.

No significant morphological differences were seen in the phloem of blightaffected tissue versus healthy tissue. Large numbers of starch grains were often observed in the parenchyma cells of the phloem (and occasionally in the ray cells of the xylem). This is consistent with previous observations (9) that roots from healthy and blight-affected trees gave strong, positive reactions with iodine-potassium iodide reagent, indicating the presence of starch in the roots, and suggests that phloem function is largely unaffected in blighted trees. This is in contrast to trees infected with citrus tristeza virus, which have poorly developed or nonexistent fibrous root systems and little or no starch in the roots (9) as a result of tristeza-induced girdling at the bud union. 


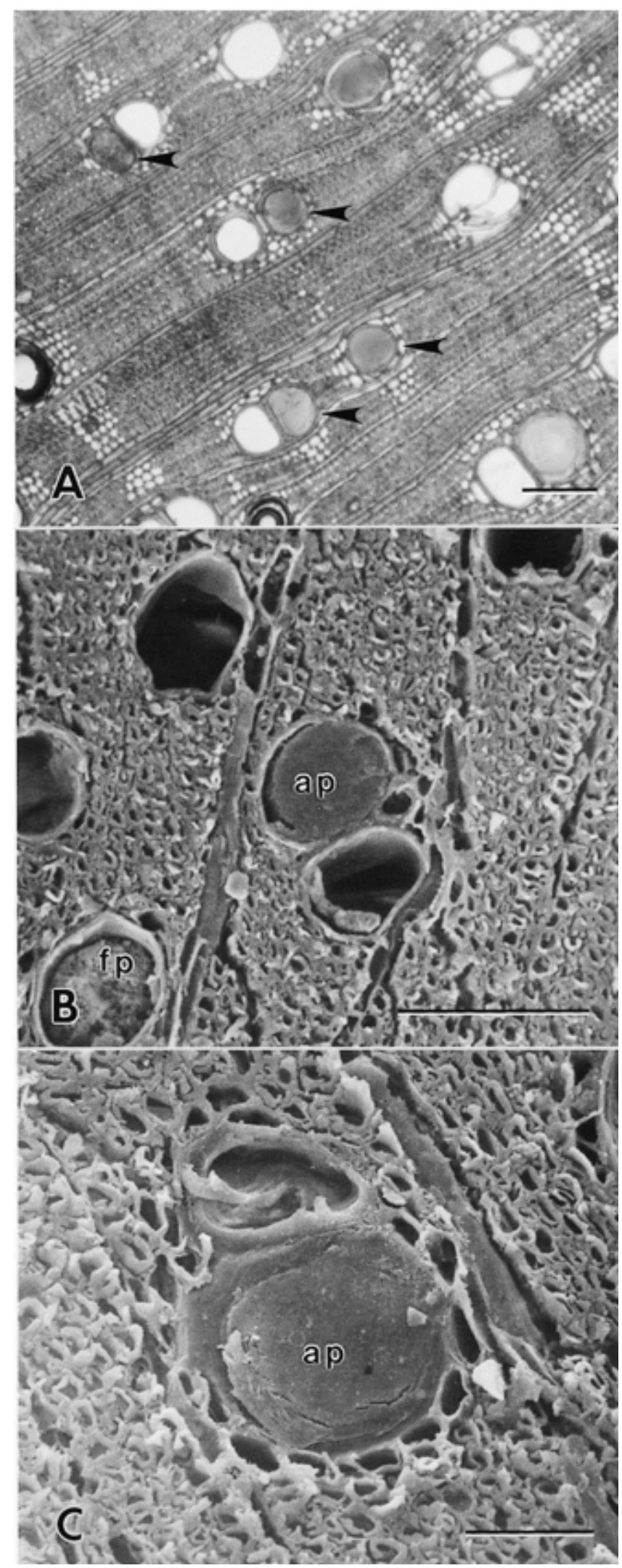

Fig. 2. Amorphous plugging of vessel elements in the trunk and large roots of blighted citrus trees. (A) Light microscopy (transverse section) from a trunk core showing numerous vessel elements (arrowheads) containing amorphous plugs. (B and C) Scanning electron microscopy (all transverse sections) showing: (B) an amorphous plug (ap) in a vessel element from a trunk core (a filamentous plug [fp] can be seen in a nearby vessel element); (C) an amorphous plug (ap) in a vessel element in a large root. (All bars $=100 \mu \mathrm{m})$
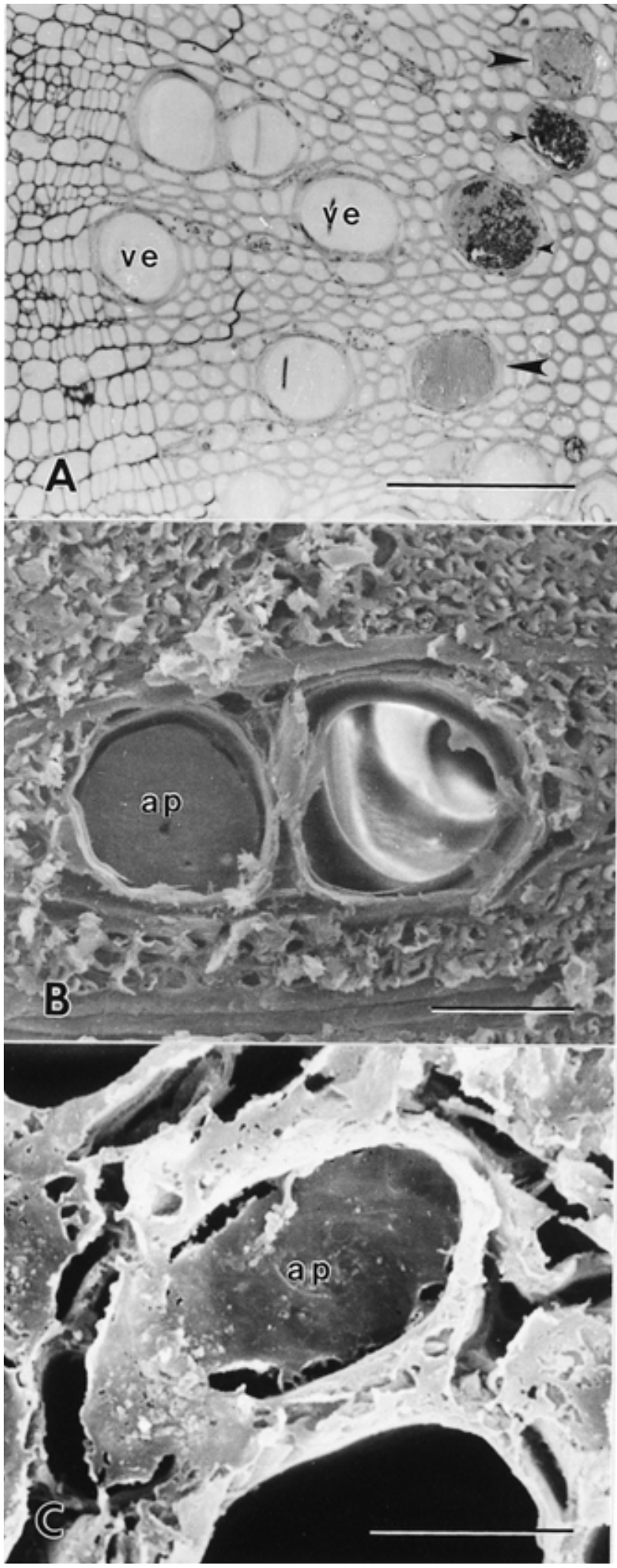

Fig. 3. Amorphous plugging of vessel elements in lateral and fibrous roots from blighted citrus trees. (A) Light microscopy (transverse section) from a fibrous root showing four vessel elements with amorphous plugs (arrowheads). Two of the vessel elements (small arrowheads) appear to contain plugs that combine both amorphous and filamentous plugs. $(\mathrm{ve}=$ vessel element; bar $=100 \mu \mathrm{m}$ ). (B and C) Scanning electron microscopy (all transverse sections) showing: (B) an amorphous plug (ap) in a vessel element in a lateral root $($ bar $=50 \mu \mathrm{m}) ;(\mathbf{C})$ an amorphous plug (ap) in a vessel element from a fibrous root. $(\mathrm{bar}=10 \mu \mathrm{m})$ 
Amorphous plugging of xylem. Amorphous plugs, similar in appearance and staining characteristics to the amorphous plugs previously associated with blight $(3,6)$, were present in the xylem of trunk cores and large roots of the blighted trees examined in this study (Fig. 2). The plugs were yellow to light gold when viewed by light microscopy and gave a positive staining reaction with phloroglucinol, indicating the presence of lignin (Fig. 2A). With SEM (Fig. 2B and C), the amorphous plugs appeared to be solid and occluded part or all of the vessel element.

Amorphous plugs similar to those in xylem from trunks and large roots of blight-affected trees were also found in the xylem of lateral and fibrous roots of blightaffected trees (Fig. 3). The fibrous roots were associated with the large roots described above via the lateral roots. Plugs were observed in fibrous roots within 3 to $4 \mathrm{~mm}$ of the tips of the roots. In transverse section with light microscopy and SEM, the amorphous plugs were identical in appearance and staining characteristics to the plugs found in the xylem of the trunk cores and large roots (Fig. 2A cf. Fig. 3A; Fig. 2B and C cf. Fig. 3B and C). Cryogenic sections retained the amorphous plugs when kept overnight in water, indicating that the plugs were not composed of water-soluble gum. These results are consistent with the amorphous plugs being identical to the plugs previously found in blight-affected trees.

By comparison, healthy trees from both Florida and California showed no plugging in the lateral roots and fibrous roots. Some filamentous plugging was observed in older vessels adjacent to the pith in larger roots. This is normal in woody plants and appears to be part of the normal aging process in citrus trees $(12,13)$.

\section{DISCUSSION}

One of the key symptoms in the field identification of blighted citrus trees is canopy decline due to reduced water flow in the vascular tissue. Amorphous plugging of xylem in the inner wood of the trunk, large branches, and large roots of blightaffected citrus trees has previously (6) been correlated with reduced hydraulic conductivity in these tissues and is probably the cause of the wilt and canopy decline that is characteristic of blight-affected trees. However, prior to this study, it has been unclear whether the amorphous plugging also occurred in the fibrous roots.

In this study, we have shown that amorphous plugging occurs in the xylem of the fibrous roots. Plugging can be found in the first 1 to $2 \mathrm{~cm}$ of the root, which represents the zone of differentiation and elongation. These areas of the root probably also represent the major site of water uptake. The presence of amorphous plugs in these areas of the fibrous roots may represent the initial site of reduced water conductivity.

The presence of a well-developed fibrous root system on blighted trees (9), as opposed to the virtually nonexistent fibrous root system in tristeza-infected trees (9), may represent a response of the blighted tree to overcome the reduced water flow resulting from the xylem occlusion. The fibrous root system is probably the functional equivalent of root hairs on other plants. Root hairs serve to increase the absorptive surface area of the root system and are a major site for water and mineral uptake; the fibrous root system carries out a similar function. Lateral root initiation usually occurs several centimeters from the root tip in most plants (8). However, we have observed (data not shown) that lateral root initiation on some fibrous roots of blighted citrus trees can occur within millimeters of the root tip. We have also found (data not shown) that where lateral root initiation occurs close to the root tip, amorphous plugging in the xylem, of the type associated with citrus blight, often occurs in the parent root adjacent to the site of root initiation. This further supports the idea that the retention of an extensive fibrous root system represents a tree's response to overcome the reduced water flow in the xylem.

The xylem of the vascular system in the trunk of blighted citrus trees has a higher vessel element density, and the vessel elements are smaller in diameter (17). The development of large numbers of small diameter vessels in the xylem of blighted citrus trees probably represents another response by the trees to overcome the reduced water flow in the xylem. Significantly, rootstocks that were considered to be susceptible to blight showed the highest level of amorphous plugging and also had the greatest change in xylem anatomy. This further reinforces the idea that the change in xylem anatomy is a response to the presence of amorphous plugging in the xylem.

\section{LITERATURE CITED}

1. Bauscher, M. G. 1990. Electrophoretic and immunological evidence of unique proteins in leaves of citrus trees: Application to citrus blight detection. Electrophoresis 11:830-834.

2. Brlansky, R. H. 1993. Cytology, histopathology and histochemistry of citrus blight. Pages 237 251 in: Handbook of Cytology, Histology and Histochemistry of Fruit Tree Diseases. Alan R. Briggs, ed. CRC Press, Boca Raton, FL.
3. Brlansky, R. H., Lee, R. F., and Collins, M. H 1985. Structural comparison of xylem occlusions in the trunks of citrus trees with blight and other decline diseases. Phytopathology 75:145-150.

4. Brlansky, R. H., Timmer, L. W., Lee, R. F., and Graham, J. H. 1984. Relationship of xylem plugging to reduced water uptake and symptom development in citrus trees with blight and blightlike declines. Phytopathology 74:1325-1328.

5. Childs, J. F. L. 1954. Observations on citrus blight. Proc. Fla. State Hortic. Soc. 66:33-37.

6. Cohen, M., Pelosi, R. R., and Brlansky, R. H. 1983. Nature and location of xylem blockage structures in trees with citrus blight. Phytopathology 73:1125-1130.

7. Derrick, K. S., Lee, R. F., Brlansky, R. H., Timmer, L. W., Hewitt, B. G., and Barthe, G. A. 1990. Proteins associated with citrus blight. Plant Dis. 74:168-170.

8. Esau, K. 1965. Anatomy of Seed Plants. 2nd ed. John Wiley \& Sons, New York.

9. Garnsey, S. M., and Young, R. H. 1975. Water flow rates and starch reserves in roots from citrus trees affected by blight and tristeza. Proc. Fla. State Hortic. Soc. 88:79-84.

10. Lee, R. F., Marais, L. J., Timmer, L. W., and Graham, J. H. 1984. Syringe injection of water into the trunk: A rapid diagnostic test for citrus blight. Plant Dis. 68:511-513.

11. Nemec, S. 1975. Vessel blockage by myelin forms in citrus with and without rough-lemon decline symptoms. Can. J. Bot. 53:102-108.

12. Nemec, S., Constant, R., and Patterson, M. 1975. Distribution of obstructions to water movement in citrus with and without blight. Proc. Fla. State Hortic. Soc. 88:70-75.

13. Nemec, S., and Kopp, D. 1974. Extent of lipid vessel plugs in citrus with and without sandhill and young tree decline symptoms. Proc. Fla. State Hortic. Soc. 87:107-111.

14. Rhoads, A. S. 1936. Blight—a non parasitic disease of citrus trees. Fla. Agric. Exp. Stn. Bull. 296.

15. Smith, P. F. 1974. History of citrus blight in Florida. Citrus Ind. 55(9):13, 14, 16, 18, 19; (10):9, 10, 13, 14; (11):12, 13.

16. Vandermolen, G. E. 1978. Electron microscopy of vascular obstructions in citrus roots affected with young tree decline. Physiol. Plant Pathol. 13:271-274.

17. Vasconcellos, L. A. B. C., and Castle, W. S. 1994. Trunk xylem anatomy of mature healthy and blighted grapefruit trees on several rootstocks. J. Am. Soc. Hortic. Sci. 119:185-194

18. Weatherly, P. E. 1982. Water uptake and flow in roots. Pages 79-109 in: Physiological Plant Ecology. II: Water Relations and Carbon Assimilation. O. L. Lange, P. S. Nobel, C. B. Osmond, and H. Ziegler, eds. Encyclopedia of Plant Physiology, New Series, Vol. 12B. Springer-Verlag, New York.

19. Wutscher, H. K., Cohen, M., and Young, R. H. 1977. Zinc and water-soluble phenolic levels in the wood for the diagnosis of citrus blight. Plant Dis. Rep. 61:572-576.

20. Young, R. H. 1980. Water movement in limbs, trunks, and roots of healthy and blight-affected 'Valencia' orange trees. Proc. Fla. State Hortic. Soc. 92:64-67.

21. Young, R. H., and Garnsey, S. M. 1977. Water uptake patterns in blighted citrus trees. J. Am. Soc. Hortic. Sci. 102:751-756. 